IZA DP No. 5198

Religious Participation versus Shopping:

What Makes People Happier?

Danny Cohen-Zada

William Sander

September 2010 


\title{
Religious Participation versus Shopping: What Makes People Happier?
}

\author{
Danny Cohen-Zada \\ Ben-Gurion University \\ and IZA
}

\author{
William Sander \\ DePaul University
}

\section{Discussion Paper No. 5198 \\ September 2010}

\author{
IZA \\ P.O. Box 7240 \\ 53072 Bonn \\ Germany \\ Phone: +49-228-3894-0 \\ Fax: +49-228-3894-180 \\ E-mail: iza@iza.org
}

\begin{abstract}
Any opinions expressed here are those of the author(s) and not those of IZA. Research published in this series may include views on policy, but the institute itself takes no institutional policy positions.

The Institute for the Study of Labor (IZA) in Bonn is a local and virtual international research center and a place of communication between science, politics and business. IZA is an independent nonprofit organization supported by Deutsche Post Foundation. The center is associated with the University of Bonn and offers a stimulating research environment through its international network, workshops and conferences, data service, project support, research visits and doctoral program. IZA engages in (i) original and internationally competitive research in all fields of labor economics, (ii) development of policy concepts, and (iii) dissemination of research results and concepts to the interested public.
\end{abstract}

IZA Discussion Papers often represent preliminary work and are circulated to encourage discussion. Citation of such a paper should account for its provisional character. A revised version may be available directly from the author. 
IZA Discussion Paper No. 5198

September 2010

\section{ABSTRACT}

\section{Religious Participation versus Shopping: What Makes People Happier?}

In this paper, we first explore how an exogenous increase in the opportunity cost of religious participation affects individuals' religious participation and reported happiness using data from the General Social Survey. The exogenous shift in the cost of religious participation is a result of repealing of so-called blue laws which restrict retail activity on Sundays. We find that repealing blue laws causes a significant decline in the level of religious participation of white women and in their happiness. We do not observe any significant decline in reported happiness of other groups whose religious participation was not significantly affected by repeal. We also use repeal as an instrumental variable (IV) for church attendance and provide direct evidence that church attendance has a significant positive effect on happiness, especially for women.

JEL Classification: K10, J16

Keywords: religious participation, happiness, blue laws

Corresponding author:

Danny Cohen-Zada

Department of Economics

Ben-Gurion University

Beer-Sheva 84105

Israel

E-mail: danoran@bgu.ac.il 


\section{RELIGIOUS PARTICIPATION VERSUS SHOPPING: WHAT MAKES PEOPLE HAPPIER?}

\section{Introduction}

The economics of happiness is receiving increasing attention. For example, the determinants of happiness were the focus of a recent address by the current Chairman of the Federal Reserve System in the United States (Bernanke, 2010). Gary Becker (2010) notes that it is a puzzle why happiness has not increased in the United States over the past few decades while income increased markedly. Substantial attention has been given to research by Stevenson and Wolfers (2009) that indicates declining female happiness. This study contributes to the literature on this topic by focusing on the effect of religious participation on happiness and, in particular, on the happiness of women.

There is a relatively large literature on the determinants of happiness in economics and other disciplines. Frey (2008), Frey and Stulzer (2002), Layard (2005) and others provide useful surveys of some of the literature on happiness studies by economists. One of the key findings is that although economic growth and higher income buys some amount of happiness, the effect is either small or zero once a certain level of economic prosperity has been reached (Oswald, 1997). Recently, Powdthavee (2009) challenged this finding by showing that the effect of income on life satisfaction increased markedly when the endogeneity of income was taken into account. Some of the other determinants of happiness have been shown to be education (higher levels of education increase happiness), race (whites are happier 
than blacks), family relationships, work (unemployment has a relatively large negative effect), health, personal freedom, community and friends, and personal values such as religious beliefs (also see Kahneman and Krueger, 2006; Stevenson and Wolfers, 2009). Blanchflower and Oswald (2007) show that age has a u-shaped effect on happiness.

Another key finding in the happiness literature is that reported level of happiness has declined over the last quarter of a century in the United States, especially for white women (Blanchflower and Oswald, 2004). Stevenson and Wolfers (2009) show that the larger decline in reported happiness among women has eroded a gender gap in happiness in which women in the 1970s reported higher subjective well being than did men. In addition, they show that the larger decline in happiness among women is found across various datasets and measures of subjective well being. This decline in female happiness is paradoxical since by many objective measures the lives of women in the United States have improved during this period of time. Thus, it is extremely important to identify factors that might explain the paradoxical decline in female happiness in the last quarter century.

Studies also indicate that there is a positive correlation between religious participation and happiness (Ellison, 1990; Kahneman and Krueger, 2006; Layard, 2005; Okulicz-Kozaryn, 2009; Shehan, Bock, and Lee, 1990; Stevenson and Wolfers, 2008). Some of the reasons why religious participation might affect happiness are the promise of rewards in an afterlife, spiritual and material rewards in this life, and benefits from group membership (Azzi and Ehrenhberg, 1975; Lehrer (forthcoming); Sacerdote and Glaeser, 2001). However, no study has shown that religious participation has a causal effect on happiness. Further, research by Azzi and Ehrenberg (1975), Barro and McCleary (2003), Gruber, 2005, and McCleary and 
Barro (2006) indicate that religious participation is endogenous with various economic and demographic variables and thus is likely to be endogenous with happiness as well. Indeed, Frey (2008) makes the important point that many variables that are used to estimate happiness could be a result of happiness or correlated with determinants of happiness. This could be the case with estimates of religiosity on happiness, the focus of this study. Obviously, the direction of the bias is ex ante ambiguous because it is not clear whether more or less happy individuals select into religious activities.

In this paper, we explore how an exogenous increase in the opportunity cost of religious participation affects individuals' reported happiness with data from the General Social Survey (GSS). Following Gruber and Hungerman’s (2008) (hereafter GH) novel approach, we identify the exogenous shift in the cost of religious participation from the repeal of so-called blue laws which regulate commerce on Sundays. The logic is that when blue laws are repealed, individuals can choose secular activities, such as working or shopping, that were heretofore unavailable on Sundays. This increases the opportunity cost of religious participation and church attendance subsequently falls. While GH estimate the effect of repealing blue laws on risky behavior by teenagers, we estimate the effect of blue law repeal on happiness. We also use repeal as an IV for church attendance and provide IV estimates of the effect of religious participation on happiness.

The historical background on blue law repeal in the United States indicates that since the 1950s, different states repealed their blue laws in different years. Overall, the United States went from almost a total ban on entertainment, sports, and retail activities in the nineteenth century to almost no restrictions in the 1960s and 1970s (McCrossen, 2000). The reasons for repeal varied by state and did not seem to 
be a result of a decline in religiosity prior to repeal (Gruber and Hungerman, 2008). The main reason for blue law repeal was that they were found to be unconstitutional as a result of a Supreme Court ruling on what activities could be prohibited by a state (Gruber and Hungerman, 2008). Starting in the 1950s, orthodox Jews on the east coast who kept the Sabbath from sundown Friday until sundown on Saturday were arrested for violating blue laws. This resulted in a number of court cases regarding their constitutionality. In 1961, a number of Supreme Court rulings resulted in a finding that states could pass such laws only to protect the health and general welfare of their residents. This had the effect of further eroding the power of the state to restrict Sunday activities. Other reasons for blue law repeal were actions by a key individual in a state or lobbying by regulated industries. Thus, historical evidence does not suggest that blue laws were repealed simply because of declining religiosity. ${ }^{1}$ Formally, we deal with any concern regarding the exogeneity of repeal in the empirical section.

We find that blue law repeal causes a significant decline in the level of religious participation of white women and in their happiness. We do not observe any significant decline in reported happiness for other groups whose religious participation was not significantly affected by the repeal. We provide strong evidence that both the decline in religious participation and happiness due to repeal are causal. We further show that the decline in happiness due to repeal is neither work-related nor related to the behavior of the respondent's teenage children. Finally, we provide IV estimates indicating that church attendance has a significant positive effect on happiness, especially among women. Moreover, we show that this factor (religious

\footnotetext{
1 For additional background information on blue laws in the US see Goos (2005), Laband and Heinbuch (1987), Gerber, Gruber and Hungerman (2008), and Gruber and Hungerman (2008).
} 
participation) explains about one third of the "unexplained" decline in female happiness in the last twenty-five years.

Our finding that blue law repeal caused a decline in religious participation is consistent with the economic approach to the allocation of time as developed by Becker (1976) and others: An increase in the opportunity cost of attending church (by reducing prohibitions on retail activity on Sundays) should result in lower levels of church attendance other things being equal and more shopping on Sundays. Further, as the incentive to allocate less time to church and more time to other activities (shopping, work on Sundays, etc.) increases, there may be an even greater (social multiplier) effect on how households allocate their time (Becker and Murphy, 2000).

We then discuss several explanations for why individuals reduced their frequency of religious participation for shopping if it makes them less happy, and why do they not return to the Church after realizing that they had been happier before? Although these findings seems somewhat surprising, they are in line with other evidence from economic literature that indicates that individuals do not always choose the option that makes them happier (Frank, 1988; Gruber and Mullainathan, 2002; Laibson, 1997; O’Donogheu and Rabin, 1999; Offer, 2006; Thaler and Benartzi, 2004; Thaler and Shefrin, 1981; Thaler and Sunstein, 2003 and 2009). Kahneman and Kruger (2006) and Kahneman and Thaler (2006) provide good reviews of this literature. Some possible reasons for this kind of behavior include problems of self control, having present-biased preferences, maximizing utility and not happiness (happiness is only one component in the utility function), and making errors in predicting future outcomes. We discuss these potential reasons for the decline in happiness in detail in section 4. 
The paper is organized as follows. Section 2 describes the data. The empirical analysis is presented in section 3. In section 4 we explore several explanations for our findings. Conclusions are presented in Section 5.

\section{Data}

The primary data source for this study is the National Opinion Research Center's “General Social Survey’ (GSS). The GSS is a cross-sectional national survey of individuals in the United States who are at least eighteen years old and live in a noninstitutional setting. It has been undertaken either annually or biannually since 1972 . The GSS has been one of the key data sources for research on happiness in the United States.

Following GH, we select respondents who either live in states where there was a discrete clear and significant change (repeal) in the prohibition of retail activity (socalled blue laws) on Sundays for the 1973 to 1998 period or where there was no change at all. This approach leaves us with respondents from sixteen states: ten states with policy changes (Indiana, Minnesota, North Dakota, Tennessee, Texas, Virginia, and Vermont) and six states which serve as controls since policy did not change during this period (Florida, Iowa, Kansas, Ohio, Utah, and Washington). ${ }^{2}$ Data for the exact year blue laws changed in a state are excluded because it is not clear what effect they would have in the year of change. We also use data for Catholics and Protestants because they are more likely to attend church on Sundays. Non-Christian

\footnotetext{
${ }^{2}$ The time of repeal for each state is reported in Table 1 of Gruber and Hungerman (2008). GH mention the reasons for dropping the remaining states from the analysis: in some states, blue laws regulations were made at the county and city levels while our data are at the state level; in a few states they could not verify when blue laws were repealed; four states were dropped because there were too many exceptions to their laws; and there were seven states that did not have retail blue laws at any time during the period of our analysis. We re-estimated our central regressions adding these western states and found that they are similar to those presented here.
} 
religions and respondents with no religion are excluded. About $90 \%$ of the GSS sample is either Catholic or Protestant.

Our measure of religious participation is based upon a question in the GSS on church attendance. Respondents were given nine possible responses to a question on their frequency of attending religious services. The possible responses are never, less than once a year, about once a year, about once or twice a year, several times a year, about once a month, two to three times a month, nearly every week, every week, and several times a week. The data indicate that respondents who have higher levels of attendance report that they are happier. For example, respondents who attend religious services more than once a week are about twice as likely to say that they are very happy relative to respondents who never attend religious services (Table 1).

Other data that we use from the GSS includes household income, educational attainment (relative to high school graduate), male, black, Hispanic, age, age squared, marital status, religion, number of babies, pre-teenagers and teenagers in the household, living in one of the twelve largest metropolitan areas, living in one of the thirteenth to one hundred largest metropolitan areas (the type of residence variables are relative to areas outside of the one hundred largest metropolitan areas), and region (relative to south). The (real) income variable is derived from categorical data from the annual or biannual surveys of the GSS. For this reason, some of the observations are "top coded.” For the "top coded" values the GSS fits a Pareto curve to the upper end of the distribution and uses the mean of this interval (see Ligon, 1989).

Our key variable is a measure of happiness which has three categories: not happy, pretty happy and very happy. We dichotomized this variable into two categories ("not happy” versus at least “pretty happy”) because it is not clear whether "very happy” is significantly different from the answer "pretty happy.” For example, Kahneman and 
Krueger (2006) note that respondents may interpret and respond to questions on subjective well-being differently. One person may not use superlatives to indicate his level of happiness while another person might. In the case of the former, the respondent might say that he is pretty happy while the other person might say he is very happy. The response "pretty happy" for the first person could be equivalent to the response "very happy" for the second person. For this reason, it is important to compare a response regarding level of happiness to a response that has a more clear meaning like not happy. ${ }^{3}$

In addition, we also adjust for a set of state/year controls including percent African-American in a state, percent foreign-born in a state, inflation-adjusted per capita disposable income, and the rate of insured unemployment in a state. Summary statistics for the data set are provided below (Table 2).

\section{Empirical Estimation}

\section{A. The repeal of blue laws and church attendance}

We begin by estimating the effect of repealing blue laws on church attendance. Following GH, we estimate a "difference in difference" equation of the form

\footnotetext{
${ }^{3}$ Another reason we dichotomized the happiness measure is that multinomial logit and multinomial probit estimates were found to be non-ideal. For example, multinomial logit has the property of independence from irrelevant alternatives (IIA), which assumes that the relative probabilities of choosing between two alternatives are independent of the existence and attributes of any other alternative. We tested the validity of the IIA assumption using the Hausman and McFadden (1984) test and found that it was violated in many of our estimates. Similarly, there were problems with multinomial probit estimates. First, the estimates failed to converge for several sub-samples. Second, because our specification included both state and year fixed effects and also a time trend for each state, multinomial probit estimates as well as ordered probit estimates could be biased due to the incidental parameter problem (Neyman and Scott, 1948). Ignoring these econometric problems, the vast majority of the results with multinomial logit and multinomial probit indicated that repealing blue laws significantly affected the probability of being pretty happy relative to not happy but did not affect the probability of being very happy relative to pretty happy. In this case, one does not lose much information by dichotomizing the happiness measure to have only two categories which are "not happy" relative to "at least pretty happy". In fact, logit regressions are found to yield much cleaner results than ordered probit or ordered logit regressions. Ordered models did not provide a good fit since they have the assumption that the effect of $x$ on the dependent variable is the same no matter where one dichotomizes the dependent variable. This assumption is far from being satisfied in our data.
} 


$$
\mathrm{A}_{\mathrm{ist}}=\text { Repeal }_{\mathrm{st}}+\mathrm{X}_{\mathrm{ist}}+\mathrm{Z}_{\mathrm{st}}+\mathrm{S}_{\mathrm{s}}+\mathrm{Y}_{\mathrm{t}}
$$

where $\mathrm{A}_{\text {ist }}$ is church attendance for individual $\mathrm{i}$ in state s at time t; Repeal $\mathrm{st}_{\mathrm{st}}$ is a dummy variable indicating whether blue laws were already repealed (repeal=1) in state s in year $\mathrm{t}$; $\mathrm{X}_{\text {ist }}$ is a set of individual controls; $\mathrm{Z}_{\mathrm{st}}$ is a set of state/year controls; $\mathrm{S}_{\mathrm{s}}$ is a set of state fixed effects; and $\mathrm{Y}_{\mathrm{t}}$ is a set of time fixed effects. This specification allows us to test whether repealing blue laws causes a deviation from a state's mean of religious participation relative to other states at the same time. We report state clustered standard errors. Numbers are in bold when they are distinguishable from zero at the 5\% significance level.

The results presented in Column 1 of Table 4 indicate that there is a strong significant negative effect of repealing blue laws on church attendance. Repealing blue laws reduced attendance by almost a quarter index point. However, the causal interpretation of this finding relies on the assumption that conditional on the state and year fixed effects, which we include in all our estimations as part of our identification strategy, the repeal of blue laws is an exogenous event. We use several strategies to test this assumption.

First, to show that selection of the repeal variable on unobservables is at most a very minor issue, we measure the correlation between the repeal variable and our entire set of observed covariates conditional on state and year fixed effects. According to Altonji, Elder and Taber (2005), when the number of observed covariates is large enough, the amount of selection on observables can provide a guide to the amount of selection on unobservables. Column 3 of Table 3 reports the slope from a regression of the variables listed in the first column on repeal in models that also include state and year fixed effects, i.e., estimates of $\alpha_{1}$ in models such as 
$X_{\text {ist }}=\alpha_{0}+\alpha_{1}$ Repeal $_{\mathrm{st}}+\beta \mathrm{S}_{\mathrm{s}}+\mu^{\prime} \mathrm{Y}_{\mathrm{t}}$

where $X_{\text {ist }}$ denotes the value of an observable individual covariate. We report stateclustered standard errors. The results show that the association between the repeal variable and the observed covariates is weak. Except for church attendance, none of the nineteen individual-level covariates is significantly correlated with the repeal variable at the $5 \%$ significance level. Four variables are significant at the $10 \%$ level (marital status, number of babies, number of preteens and living in one of the 12 largest metropolitan areas).

Similarly, for comparison purposes, we also assess the amount of selection on church attendance (our key endogenous variable). In stark contrast, the amount of selection on church attendance is substantially larger (Column 2 of Table 3). Eleven covariates were significantly associated with church attendance at the $5 \%$ significance level. The negligible amount of selection that we found on repeal suggests that selection on unobserved individual characteristics is not a major issue. The four bottom lines of this column report similar results where the dependent variable is a state-level characteristic. That is, $\alpha_{1}$ is estimated in the form

$\mathrm{Z}_{\mathrm{st}}=\alpha_{0}+\alpha_{1}$ Repeal $_{\mathrm{st}}+\beta \mathrm{S}_{\mathrm{s}}+\mu^{`} \mathrm{Y}_{\mathrm{t}}$.

Again, none of the four state-level covariates is significantly correlated with the repeal variable at the $5 \%$ level. Since the number of state-level covariates is small, the amount of selection on observed state covariates cannot provide an indication of the amount of selection on unobserved state covariates. Fortunately, in a paper by Price and Yandle (1987) it is observed that the presence of blue laws is not significantly correlated with a large number of state covariates such as the political makeup of a 
state, the fraction of women in the labor force, the strength of labor unions and other state socioeconomic covariates. Thus, our results and their results both suggest that selection on unobserved state covariates is negligible.

We show that it is not likely that anything else caused a decline in church attendance when blue laws were repealed by focusing on a narrow interval (+2 and -2 years) around the year of the repeal and estimating univariate regressions of each of our covariates on the repeal variable. The results presented in Column 4 of Table 3 indicate that except for church attendance which declined significantly when blue laws were repealed, none of our 19 individual level covariates and 4 state-level covariates is found to be significantly associated with the repeal variable.

Following GH, we also show that there was no downward trend in church attendance at the same time of repeal. We do this by adding to the basic specification that includes state fixed effects and year fixed effects, state-specific linear time trends. ${ }^{4}$ These additional controls help us capture any reduction in church attendance over time within states that repealed blue laws. The results of this specification indicate that when state-specific time trends are added to the equation the estimated effect of blue laws on church attendance is only strengthened (Column 2 of Table 4).

We additionally rule out the possibility that blue laws are picking up a preexisting reduction in the demand for attending church (and an increase in demand for secular activities) by adding to the basic specification a placebo dummy variable that indicates two years before blue laws were repealed. If this dummy is negative and significant it would indicate that church attendance was declining prior to the repeal of blue laws and not as a result of it. The results indicate that the placebo dummy is

\footnotetext{
${ }^{4}$ When we tried to add a quadratic time trend we found that all the state fixed effects were dropped due to collinearity.
} 
insignificant (Column 3 of Table 4). Further, the estimated effect of repeal on church attendance is even stronger than in the basic specification. ${ }^{5}$

Another possible issue with the validity of our identification strategy is that another regional event occurred at the same time as repeal that also reduced church attendance. To rule out this possibility, we run the basic equation replacing the repeal variable with a placebo that gives the repeal dummy to a nearest state. The results indicate that if there were other events at the time of repeal, they only increased church attendance rather than decreased it (Column 4 of Table 4). Similarly, it could be the case that there was another event that influenced only states of a given size (for example an event that influenced only small states or big states). To rule this possibility out, we estimate the basic equation replacing the repeal variable with a placebo that gives the repeal dummy to a state with the most similar population size. The results again indicate that the placebo is not significant (Column 5 of Table 4).

Finally, we also run a permutation test in order to rule out the possibility that the driving force in the decline in church attendance is not the repeal of blue laws but rather another event. This test is designed to determine whether the estimated effect of the repeal variable is significantly more negative than the effect on church attendance of a placebo that randomly assigns a year of repeal to each state so that we can reject the null Hypothesis $\mathrm{H}_{0}$ that $\mathrm{b}($ repeal $)=\mathrm{b}$ (placebo). The test is as follow. First, we randomly assign a placebo year of repeal between 1955 and 1991 to each of our states (the earliest and the latest years of repeal in our data) and re-estimate the basic equation replacing the repeal variable with the placebo variable. We iterate this procedure 10,000 times. The one-sided p-value of this test is calculated as the

\footnotetext{
${ }^{5}$ This placebo equals one only in the two year before the repeal and returns to be zero after the year of repeal. We also performed a somewhat different test for reverse causality. We took only the observations before the year of repeal and estimated the basic equation replacing the repeal variable with a placebo for the two years prior repeal. Again, the placebo was found to be insignificant.
} 
proportion of permutations where the coefficient of the placebo on church attendance is equal to or lower than -0.209 (the coefficient of the repeal variable on church attendance reported in Column 1 of Table 4). The permutation test rejects the null hypothesis that the coefficient of the placebo equals the coefficient of the repeal at the 5\% level. It is noteworthy to mention that GH provide an additional indication that it is not other factors that reduces church attendance. They show that there is a negative effect of repeal on being a member of church groups, but no effect on other groups such as fraternal orders, political clubs, sport clubs and hobby clubs. If there is an omitted factor that reduces church attendance, it is likely to affect other types of social participation as well. Thus, we have very strong evidence that conditional on year and state fixed effects the repeal variable is an exogenous event.

Table 5 reports on the effect of repeal on church attendance by gender. It shows that while the repeal coefficient is negative for both males and females in all three specifications, it is significant at the $5 \%$ level for females and not significant for males. Table 6 indicates that the largest decline in church attendance is for white women. The coefficient for the other groups is negative but insignificant.

\section{B. Blue laws, religiosity and happiness}

First, we present estimates from naïve logit regressions of the effect of church attendance on happiness for the full sample and by gender. The results indicate that in all of the estimates church attendance has a substantial and very significant positive effect on happiness (Table 7). For the full sample, a one index point increase in church attendance is associated with a $10.7 \%$ increase in the odds ratio of being at least pretty happy relative to not happy. This is a sizeable effect: an increase in church attendance from "never" to "every week" has almost the same effect on happiness as 
the effect of being married relative to not married. Columns 2 and 3 of Table 7 present similar logit estimates by gender. These estimates indicate that church attendance always has a very significant positive effect on happiness among both men and women. In addition, this effect is found to be larger for males than for females. Similarly, Columns 4-6 report results from linear probability models, which produce similar marginal effects.

Estimating the effect of repealing blue laws on happiness can shed light on the effect of religious participation on happiness. If religious participation indeed increases happiness, the repeal of blue laws may lead to a decline in happiness among those whose religious participation has fallen. A logit estimate of the effect of the repeal on happiness is presented below (Column 1 of Table 8). This estimate takes the following form:

$$
\mathrm{H}_{\mathrm{ist}}=\text { Repeal }_{\mathrm{st}}+\mathrm{X}_{\mathrm{ist}}+\mathrm{Z}_{\mathrm{st}}+\mathrm{S}_{\mathrm{s}}+\mathrm{Y}_{\mathrm{t}}
$$

where $\mathrm{H}_{\text {ist }}$ is our happiness measure for individual $\mathrm{i}$ in state $\mathrm{s}$ and time t. The other variables are as reported in equation (1). The results show that the effect of repeal on happiness is negative and almost significant at the $5 \%$ level. The repeal of blue laws decreases the odds ratio of being at least pretty happy relative to not happy by about 17\%. This is half as large as the effect of not finishing high school (relative to finishing high school) on happiness.

As we mentioned in note 2, the happiness measure originally had three categories "very happy" "somewhat happy" and "not happy". We decided to dichotomize this happiness measure to two categories (“not happy” relative to at least “somewhat happy”). Alternatively, we could choose to dichotomize it differently and have two other categories ("very happy" relative to "somewhat happy" and "not 
happy”. We chose our dichotomization based upon the vast majority of results with multinomial logit and multinomial probit indicating that repealing blue laws significantly affected the probability of being "pretty happy” relative to "not happy.” It did not affect the probability of being "very happy” relative to "pretty happy.” In Column 2, we present the effect of blue law repeal on happiness when the other dichotomization is used. It indicates that the size of the repeal coefficient declines by more than $50 \%$ and becomes statistically insignificant. This finding provides further evidence that our original dichotomization is more appropriate.

A regression in which linear time trends for each state are included indicates that this addition to the regression only strengthen the effect of repealing blue laws on happiness (Column 3 of Table 8). A third specification that adds a placebo dummy to the estimation to capture preexisting declines in happiness indicates that the placebo dummy is not significant while the repeal dummy still has a significant negative effect on happiness (Column 4 of Table 8). ${ }^{6}$ A specification with a placebo that gives the repeal dummy to a nearest state also indicates that the placebo is very insignificant (Column 5 of Table 8). Similarly, a specification with a placebo that gives the repeal variable to a state with the most similar population size indicates that the placebo is positive and significant at the $10 \%$ level (Column 6 of Table 8). This implies that if there was any event at the same time of repeal that influenced only states of a given size, it only increased the level of happiness. Taken together, we have strong evidence that the decline in happiness due to the blue law repeal is causal.

If repealing blue laws decreases happiness through its negative effect on religious participation, the effect should be stronger for women whose religious participation has fallen more sharply and more significantly. Also, for the same

\footnotetext{
${ }^{6}$ We also used a somewhat different test for reverse causality. We took only the observations before the year of repeal and estimated the basic equation replacing the repeal variable with a placebo for the two years prior repeal. Again, the placebo was found to be insignificant.
} 
reason, the effect should be stronger for white women than for black women. The results by gender are reported below (Table 9). We do not observe any significant decline in happiness in any of our three specifications for men. However, for women all three specifications indicate a significant decrease in happiness. ${ }^{7}$ Also, a permutation test (with 10,000 permutations) that the effect of a placebo that randomly assigns a year of repeal to each state equals the effect of the real repeal variable on happiness is rejected at less than the $2 \%$ significance level for women, but only at the $12 \%$ level for the general sample that includes men. In addition, a significant decline in happiness is observed only among white women (Table 10). ${ }^{8}$

These results are very interesting since both Blanchflower and Oswald (2004) and Stevenson and Wolfers (2009) show that declines in happiness during the last three decades has been larger for women than for men. Blanchflower and Oswald (2004) also find that the largest decline in happiness was among white women. Stevenson and Wolfers note that the larger decline in happiness for women is a paradox because the economic status of women in the United States has improved during this period of time. Our finding that the effect of blue law repeal on happiness is larger for women than for men identifies one factor that might explain this

\footnotetext{
${ }^{7}$ We also estimated the effect of blue law repeal on happiness when the other dichotomization is used. It indicates that the size of the repeal coefficient declines substantially to -0.095 and becomes statistically insignificant. This finding provides further evidence that our original dichotomization is more appropriate.

${ }^{8}$ Similarly, if blue law repeal reduces happiness only through its negative effect on church attendance it should only affect church attendees. Separate results for attendees and non-attendees support our predictions: While the repeal dummy is positive and insignificant for non-attendees it is negative and significant for attendees. Also, the effect of repeal on happiness is negative and highly significant for women who attended church and positive and insignificant for those who did not attend. We must note ,though, that since church attendance is measured at the year of the survey, it is possible that many attendees might have become non-attendees as a result of the repeal of blue laws, in which case breaking the results by attendance is problematic. This problem become somewhat less of an issue since as indicated by GH with the same data (page 844), repealing blue laws had no effect on the "not attending at all" category, implying that blue laws did not cause individuals to drop out of church-going but rather to go less.
} 
paradoxical decline in female happiness. It also explains why the decline in happiness was larger for white women than for black women.

Finally, we show that our estimated repeal effects on church attendance and happiness are not likely to be biased because of omitted individual or state characteristics. We re-estimate the model for the whole sample without individual and state controls. The results indicate that the significant negative effects of repeal on church attendance and happiness are not sensitive to the inclusion of individual and state controls (Table 11).

It is possible that the decline that we observe in reported happiness among females is driven by the blue law repeal in a particular state. We treat this concern by checking the robustness of our repeal estimates if one state is excluded. We find that the negative effect of repeal on happiness among females is very robust to the exclusion of one state at a time (Table 12). For example, for the basic specification, while the coefficient of repeal on happiness is -0.47 (when all states are included), the coefficient ranges from -0.40 to- 0.59 and remains significant at the $5 \%$ level. It is also the case with the state-specific time trend specification. While the coefficient of repeal on happiness is -0.56 (when all states are included), the coefficient ranges from -0.49 to -0.79 and remains significant at the $5 \%$ level.

To further support our argument that both the decline in religious participation and happiness are causal we also focus on a discontinuity sample of two years before the year of repeal to two years after it. The results, reported in Table 13, indicate that religious participation declined significantly (at the 5\% level) after the repeal. Similarly, the decline in reported happiness is significant at the $7.2 \%$ and $6 \%$ level for the entire sample and for females, respectively. 


\section{C. Instrumental variable estimates of the effect of religious participation on happiness}

We have provided indirect evidence that blue law repeal reduced happiness through its effect on church attendance. We next want to present direct evidence that church attendance has a positive causal effect on happiness by using the repeal of blue laws as an instrumental variable for church attendance.

Although we showed that the decline in religious participation due to the repeal of blue laws is convincingly exogenous, it does not necessarily follow that the repeal variable is a valid instrumental variable for religious participation. For validity, it should affect happiness only through religious participation. Although repeal may affect happiness through several other channels, we show that the effect of repeal through other channels is negligible and not a major concern.

First, it is possible that repeal caused a decline in happiness because respondents had to start working on Sundays once blue laws were repealed. Survey data indeed indicate that retail employees do not like to work on Sundays (Martin and Wittmer, 2009). We rule out this possibility by performing three tests. First, we

provide separate results for workers and non-workers. If part of the reduction in happiness is through working on Sunday, we should observe a larger decline in happiness for workers than for non-workers. Table 14 indicates that this is not the case. The reduction in happiness for non-workers is even larger than for the population in general (Columns 1 and 2). Also, the reduction in happiness is similar for working and non-working women (Columns 3 and 4). Second, if happiness declined because of working on Sunday, we might observe a decline in job satisfaction and an increase in number of weekly hours worked once blue laws were 
repealed. Table 15 reports the effect of repeal on job satisfaction as well as on number of hours worked. The results are reported for the entire sample and for women. Job satisfaction is measured categorically with higher values indicating lower levels of satisfaction. We find that neither job satisfaction nor hours worked were significantly affected by repeal. We also focus on a discontinuity sample of two years before the year of repeal to two years after it. The results, reported in Table 13, indicate that neither job satisfaction nor weekly hours worked changed significantly after repeal. However, we are not able to observe whether respondents were required to work on Sundays. Data in the GSS are not available on this.

Second, it is possible that repeal caused a decline in individuals' reported happiness, regardless of their level of church attendance. For example, respondents’ teenage children no longer want to go to church with their family. Thus, church going loses its value as an activity that gathers all of the family together. Similarly, it could be the case that parents are less happy because after repeal their children are more frequently engaged in risky behavior (Gruber and Hungerman, 2008) or because they "hang out" at malls too often. If the decline in happiness is related to the behavior of the respondent's teenage children we should observe a larger decline in happiness for women with a larger number of teenage children. To test this possibility, we added to the basic specification an interaction term between the repeal variable and the respondent's number of teenage children. The results, reported in Table 16, indicate that the interaction term is insignificant and also has a positive sign rather than a negative one. This implies that the decline in happiness is not larger among respondents with more teenage children.

Third, one might argue that respondents may become less happy after repeal, regardless of their level of church attendance, because Sunday loses its spiritual 
meaning and become less special when malls are open and people can work on Sundays. That is, there might be a negative externality from making Sunday less a day of rest. Although we cannot rule out this possibility completely, our evidence indicates that this explanation for the decline in happiness is not likely. If this were the case, it is quite likely that we might have been able to show a decline in happiness for men as well.

Further, we argue that the effect of repeal on happiness through other channels seems to be negligible since we observe a significant decline in happiness only among those groups who reduced their church attendance significantly after repeal. For example, a significant decline in happiness is found among women and not among men who did not significantly reduce their level of church attendance after repeal. Similarly, a significant decline in happiness is found only for white women and not for black women who did not significantly reduce their church attendance. In addition, as mentioned in note 2, while we observe a significant effect of repeal on happiness for attendees, we do not observe any significant effect for non-attendees. Also, the effect of repeal on happiness is negative and highly significant for women who attended church and positive and insignificant for those who did not attend. These are additional indications that the effect of repeal on happiness works through the decline in religious participation.

Column 1 of Table 17 reports instrumental variable (IV) estimates of our basic specification. The results indicate that church attendance has a substantial positive effect on happiness. A one unit increase in the church attendance index increases the probability of being at least pretty happy relative to not happy by more than 7 percentage points. A limitation of this estimate is that although the repeal dummy is significant in the first stage (Table 3), the F-statistic on the excluded instrument only 
passes the least strict test required by Stock and Yogo (2005) for the instrument not to be considered weak. Consequently, inferences about the significance of the causal effect of church attendance on happiness might not be reliably based on conventional t-statistics. Therefore, to test the significance of the causal effect of church attendance on happiness we use the Anderson and Rubin (1949) test. This test is robust to weak instruments and also takes into account the clustered structure of our data. The results indicate that church attendance is almost significant at the $10 \%$ level.

When state specific time trends are added to the estimate, the magnitude of the effect of church attendance on happiness slightly decreases (Column 2 of Table 17), but the causal effect of church attendance on happiness becomes significant at the 5\% level (according to the AR test). Thus, although the instruments are not as strong as one might like, the AR test indicates that they are strong enough to provide significant results. The effect of church attendance on happiness remains significant at the $5 \%$ level also when a placebo dummy is added to the basic specification (Column 3 of Table 17).

We also re-estimated the model without individual and state controls to show that the significant effect of church attendance on happiness is not sensitive to omitted individual or state characteristics. The results, reported in Column 4 of Table 17, indicate a slightly stronger effect of church attendance on happiness. We also report IV estimates among females. We cannot provide IV estimate for men since blue law repeal (our instrument) is not powerful enough in explaining religious participation for men (see Table 5). The results, reported in Column 5 of Table 17, indicate that the effect of church attendance on happiness for females is much larger and more significant than in the whole population. This finding is consistent with the higher rate of church attendance by women. Our results thus provide strong evidence that church 
attendance has a positive causal effect on happiness, especially among women. The magnitude of the church attendance effect on happiness is larger in the IV estimates of religious activity. For example, an adverse event might have a negative effect on happiness and a positive effect on church attendance. ${ }^{9}$

Eight western states that never had blue laws (Arizona, California, Colorado, Idaho, Nevada, New Mexico, Oregon, and Wyoming) were excluded from the analysis. GH also excluded these states. Their results did not change markedly when these states were included. We also re-estimated our models including the western states. Most of the results were the same when the western states were included. However, there were a few small differences although our key results did not change in any important way. The negative effect of repeal on the happiness of women was still very strong.

\section{Possible explanations}

In this section, we discuss several explanations why church attendees who derive more satisfaction from religious participation than from shopping did not continue to attend church at the same rate after blue laws were repealed. In addition, we discuss why they did not return to church if this made them happier? Although these findings are somewhat surprising, they are in line with other evidence from research indicating that individuals do not always choose the option that makes them happier for several possible reasons.

\footnotetext{
${ }^{9}$ It is noteworthy that our estimation strategy allows us to identify the effect of religiosity on happiness relative to shopping. A different policy change, such as one that outlawed religious participation, might involve a different tradeoff and thus lead to a different estimated happiness effect.
} 
First, economic theory suggests that people maximize their utility and not their happiness. Happiness should be viewed as one component in the utility function rather than utility itself. That is, individuals do not necessarily choose to do things that make them happier but rather may rationally choose to sacrifice their happiness for other behavior that gives them greater utility (Becker, 2010). In fact, Kimball and Willis (2006) note that happiness is not necessarily a good thing "if something more important is sacrificed in order to obtain that happiness.” This explanation makes sense in our context if individuals choose shopping over religious participation not as an entertainment but rather because they view shopping as something necessary for the functioning of the household.

Second, Kahneman (1999) and Kahneman and Thaler (2006) suggest that although individuals maximize "decision utility" they do not always maximize "experienced utility". That is, at the time of the decision they can only predict how much utility they are going to derive from each choice option and sometimes they make errors in predicting future utility. According to Kahneman and Thaler (2006), this is more likely to happen when the decision maker is unfamiliar with the experience he faces or when the temporal gap between the time of the decision and the time of consumption is long. For example, if an individual thinks that he would be happy if he marries someone with certain attributes, it does not necessary follow that he would actually become happy in practice. On the other hand, as Kahneman mention, people are rarely surprised by the taste of the second spoonful from a bowl of soup because they are already familiar with this taste. We argue that in our case the explanation of making an error in predicting future utility it is less likely. Unlike certain decisions, such as signing a three year cell-phone contract, the attendance/shopping decision is familiar to the decision maker. Furthermore, this 
decision is reversible in the sense that after a month one can choose to go back to church. Since one makes the decision Sunday after Sunday, it makes sense that one would learn in the long run about the best decision. In addition, individuals who made a mistake by reducing their church attendance for shopping are likely to correct the mistake if they notice them less happy due to the switch from religious participation to shopping. It does not make sense that individuals do not notice that religious participation makes them happier when they make the same decision every week.

We provide further evidence on this by selecting observations after repeal and running a regression of religious participation on number of years after repeal, controlling for our entire set of control covariates. If people left the church because they made a mistake we should observe a learning process according to which people return to the church as time passes after repeal. However, the results presented in Table 18 indicate that the coefficient of years after the repeal is insignificant and for women it is also negative rather than positive. Thus, we do not observe any learning process as time passes after repeal. However, it could be the case that the learning process is slow and imperfect and that distorted decisions might be preserved over time, especially regarding goods and activities that have intrinsic characteristics like religion (Frey, 2008).

Third, research shows that individuals might not choose the best option because of problems of self control. In our case, it is possible that individuals did not return to attending church as much even after they noticed that they were happier before because shopping like watching TV or smoking cigarettes is addictive and provides higher immediate satisfaction than religious participation. Consequently, individuals may choose this activity even if they know that in the long run they will become less happy because they cannot control their impulse to go shopping. There 
are several such examples in the economic literature. One relevant example is the case of watching television. In the United States and Europe the average person spends several hours per day watching TV. Layard (2005), Frey (2008), and others provide evidence that watching TV reduces happiness. Some of the evidence that they present is experimental where access to TV was introduced into areas that did not previously have it. Frey argues that TV watching represents a self-control problem where the benefits are immediate while the costs are in the future. This could also be the case in our study where the benefits from activities that are a result of repeal (e.g., shopping) are immediate while the costs from reduced church attendance are in the future. Frey (2008) further notes that individuals tend to underestimate the utility that they receive from activities with strong intrinsic attributes like time spent in family and (in our case) church-related activities while they overestimate the utility that they receive from goods and activities that have strong extrinsic attributes like most consumer goods. He further argues that distorted decisions tend to be preserved over time because there is "little or no learning" about the utility of their actions.

Finally, another explanation for why people choose to reduce church attendance for shopping even if it makes them less happy is that they have present biased preferences. Shopping like watching TV and smoking cigarettes provide high immediate satisfaction. However, this satisfaction remains only at the time of consumption and certainly not much longer than that. On the other hand, satisfaction from religious participation might not be immediate. Instead, in requires persistence over a period of time. Thus, the choice between shopping and religious participation might be between immediate lower satisfaction and longer run higher satisfaction. If respondents have present biased preferences they discount the future highly and 
therefore they may prefer the lower immediate satisfaction from shopping over the larger future satisfaction from religious participation.

The literature indicates that broadening the choice set of economic agents or lifting a constraint from their choice set does not necessarily imply an increase in their utility or their happiness. Thaler and Sunstein (2009) provide many examples of this. For example, guests at a dinner party might prefer not to have the option of eating more cashew nuts before dinner. Also, they show that a Swedish plan that provided more choice options for pensions resulted in poorer choices. The reason for this was that people were not given adequate help to make good choices. This was also the case in the expansion of health care benefits in the United States: They were given too many choices and not enough assistance in evaluating the alternatives.

Similarly, imposing new constraints on an agent's choice set does not necessarily imply a decrease in their utility as one would expect according to the traditional rational choice model. For example, in a related study on happiness, Gruber and Mullainathan (2005) find that cigarette taxes seem to make smokers happier because at least some smokers have a problem of self-control. Once again, Thaler and Sunstein (2009) provide many additional examples. For example, some states try to help individuals with a gambling addition by letting them place their name on a list that bans them from casinos. Also, Thaler and Shefrin (1981) and Thaler and Benartzi (2004) show that because individuals lack self-control they need help in making decisions regarding savings. Finally, Frank (1999) and Layard (2005) argue that higher income results in competitive pressures to acquire a higher status in consumption relative to others. This results in a continual escalation in consumption standards that damages well-being. 


\section{Summary and concluding remarks}

One of the shortcomings in the literature on happiness is that there is paucity of empirical evidence on whether there is a causal relationship between many of the correlates of happiness and measures of happiness. The results of this study provide support for a causal relationship between one of these correlates-religious participation-and happiness. We show that for women the repeal of blue laws has a causal negative effect on religious participation and a negative effect on happiness. We also provide direct evidence that religious participation has a positive direct causal effect on happiness using repeal as an IV for church attendance. Our results thus identify one factor that might have contributed to declining female happiness in the United States over time as indicated by Blanchflower and Oswald (2004) and Stevenson and Wolfers (2009).

As an additional indication that religious participation explains an important part of the decline in female happiness, we run happiness on a time trend with and without religious participation controlling for our entire set of control covariates. The results are summarized in Table 19. Column 1 indicates that if religious participation is not included in the regression, the probability of a woman with given characteristics is very happy or somewhat happy (relative to not happy) decreases significantly every year by 0.9 percentage points. However, when we include religious participation in the estimate and instrument for it using repeal (Column 2), we observe that religious participation is significant at the 5\% level and the decline over time is reduced to 0.6 percentage points per year, and becomes insignificant. That is, when religiosity is added to the equation we find that the probability of a woman with given characteristics to be at least somewhat happy relative to not happy did not decrease significantly over time. This indicates declines in religious participation by women is 
one important factor that might explain declines in female happiness both absolutely and relative to men over the quarter century that we examined (1973-1998). ${ }^{10}$ Identifying the causal effect of other determinants of happiness and checking whether they can explain changes in happiness over time is an avenue for future research on this topic.

\section{Acknowledgements}

We are grateful to Todd Elder, Naomi Feldman, Daniel Hungerman, Moshe Justman, Evelyn Lehrer, Avner Offer and Oren Rigbi for their valuable comments and suggestions. We are also grateful to Daniel Hungerman and Jonathan Gruber for providing data.

\footnotetext{
${ }^{10}$ For men, both with and without including religiosity in the equation, we do not observe any significant decline in happiness over time (See columns 3 and 4 of Table 19).
} 


\section{References}

Altonji, Joseph G., Todd E. Elder, and Christopher R. Taber. 2005. "Selection on Observed and Unobserved Variables: Assessing the Effectiveness of Catholic Schools.” Journal of Political Economy, Vol. 113, No. 1, pp. 151-184.

Anderson, T. and H. Rubin. 1949. "Estimation of the Parameters of a Single Equation in a Complete System of Stochastic Equations.” Annals of Mathematical Statistics, Vol. 20, pp. 46-63.

Azzi, Corry and Ronald Ehrenberg. 1975. "Household Allocation of Time and Church Attendance.” Journal of Political Economy, Vol. 83, No. 1, pp. 27-56.

Barro, Robert J. and Rachel M. McCleary. 2003. “International Determinants of Religiosity.” NBER Working Paper 10147. Cambridge, MA: National Bureau of Economic Research.

Becker, Gary S. 1976. The Economic Approach to Human Behavior. Chicago: The University of Chicago Press.

Becker, Gary S. 2010. “Happiness and Well-being.” http://english.caing.com/201001-25/100110749.html.

Becker, Gary S. and Kevin M. Murphy. 2000. Social Economics. Cambridge: The Belknap Press of Harvard University Press.

Bernanke, Ben. 2010. “Address to the graduates of the University of South Carolina. Blanchflower, David G. and Andrew Oswald. 2007. “Is Well-Being U-Shaped Over The Life Cycle?” NBER Working Paper 12935.

Blanchflower, David G. and Andrew Oswald. 2004. "Well-Being Over Time in Britain and the USA.” Journal of Public Economics, Vol. 88, pp. 1359-1386. Easterlin, Richard A. 1980. Birth and Fortune. New York: Basic Books. 
Ellison, Christopher G. 1991. "Religious Involvement and Subjective Well-Being.” Journal of Health and Social Behavior, Vol. 32, No. 1., pp. 80-99.

Frank, Robert H. 1999. Luxury Fever. Princeton: Princeton University Press.

Frank, Robert H. 1988. Passion within Reason: The Strategic Role of Emotions. New York: W.W. Norton.

Frey, Bruno S. 2008. Happiness: A Revolution in Economics. Cambridge: The MIT Press.

Frey, Bruno S. and Alois Stutzer. 2002. "What Can Economists Learn From Happiness Research?” Journal of Economic Literature, Vol. XL, No. 2, pp. 402435.

Gerber, Alan, Jonathan Gruber, and Daniel M. Hungerman. 2008. “Does Church Attendance Cause People to Vote? Using Blue Laws’ Repeal to Estimate the Effect of Religiosity on Voter Turnout.” National Bureau of Economic Research Working Paper No. 14303.

Gruber, Jonathan H. 2005. "Religious Market Structure, Religious Participation, and Outcomes: Is Religion Good for You?” Advances in Economic Analysis \& Policy Vol. 5, Issue 1, Article 5.

Gruber, Jonathan and Daniel M. Hungerman. 2008. “The Church Versus The Mall: What Happens When Religion Faces Increased Secular Competition?” Quarterly Journal of Economics, Vol. 123, Issue 2, pp. 831-862.

Gruber, Jonathan and Sendhil Mullainathan. 2005. “Do Cigarette Taxes Make Smokers Happier?” Advances in Economic Analysis \& Policy, Vol. 5, issue 1, Article 4.

Kahneman, Daniel and Alan B. Krueger. 2006. "Developments in the Measurement of Subjective Well-Being.” Journal of Economic Perspectives, Vol. 20, No. 1, pp. 3- 
24.

Kahneman, Daniel and Richard H. Thaler. 2006. "Utility Maximization and Experienced Utility.” Journal of Economic Perspectives, Vol. 20, No. 1, pp. 221234.

Kimball, Miles and Robert Willis. 2006. “Utility and Happiness.” Ann Arbor: University of Michigan.

Layard, Richard. 2005. Happiness: Lessons from a New Science. New York: The Penguin Press.

Lee, Dara. 2010. “Study, Work, or Play?” the Impact of Repealing Sunday Closing Laws on Educational Attainment, Department of Economics, Boston University.

Lehrer, Evelyn L. Forthcominga. Religion, Economics, and Demography. Routledge.

Lehrer, Evelyn L. Forthcoming. "Religion, Human Capital Investments and the Family in the United States” in Rachel M. McCleary (ed.), Oxford Handbook of the Economics of Religion.

Laibson, David. 1997. “Golden Eggs and Hyperbolic Discounting.” Quarterly Journal of Economics, Vol. 112, Issue 2.

Ligon, Ethan. 1989. “The Development and Use of a Consistent Income Measure for the General Social Survey.” National Opinion Research Center, The University of Chicago.

Martin, James E. and Jenell L.S. Wittmer. 2009. “Increasing the Desirabilty of Sunday Work.” Oxford Business and Economics Conference, July 24-26.

McCrossen, Alexis. 2000. Holy Day, Holiday: The American Sunday. Ithaca: Cornell University Press.

McCleary, Rachel M. and Robert J. Barro. 2006. "Religion and Economy.” 
The Journal of Economic Perspectives, Vol. 20, No. 2, pp. 49-72.

Newman, Barry. Nov. 6, 2008. “Car Dealers, Believing in a Day of Rest, Still

Renounce Sunday Sales.” Wall Street Journal.

Neyman, J and E.L, Scott. 1948. "Consistent estimation from partially consistent observations." Econometrica 16, 1-32.

Nielsen, Michael E. 2010. "Religion and Happiness.” http://psychwww.com/psyrelig/happy.htm.

O’Donoghue, Ted and Matthew Rabin. 1999. “Doing It Now or Later.” American Economic Review, Vol. 89, No. 1, pp. 103-124.

Offer, Avner. 2006. The Challenge of Affluence. Oxford: Oxford University Press.

Okulicz-Kazaryn, Adam. 2009. "Religiosity and Life Satisfaction.” Working Paper, Harvard University.

Oswald, Andrew J. 1997. “Happiness and Economic Performance.” Economic Journal, Vol. 107, November, pp. 1815-1831.

Powdthavee, Nattavudh. 2009. "Estimating the Causal Effects of Income on Happiness.” Department of Economics, University of York, Discussion Paper 09/02.

Sacerdote, Bruce and Edward L. Glaeser. 2001. “Education and Religion.” NBER Working Paper 8080.

Shehan, Constance L., E. Wilbur Bock, and Gary R. Lee. 1990. “Religious Heterogamy, Religiosity, and Marital Happiness: The Case of Catholics.” Journal of Marriage and the Family, Vol. 52, February, pp. 73-79.

Stevenson, Betsey and Justin Wolfers. Happiness Inequality in the United States. NBER Working Paper 14220. Cambridge, MA: National Bureau of Economic Research. 
Stock, J. and M. Yogo. 2005. “Testing for Weak Instruments in Linear IV Regressions.” In D. Andrews and J. Stock (eds.), Identification and Inference for Econometric Models. Cambridge: Cambridge University Press.

Thaler, Richard H. and Shlomo Benartzi. 2004. Save More Tomorrow: Using Behavioral Economics to Increase Employee Saving.” Journal of Political Economy, Vol. 112, No. 1, pt. 2, pp. s164-s187.

Thaler, Richard H. and H. M. Shefrin. 1981. An Economic Theory of Self-Control.” Journal of Political Economy, Vol. 89, No. 2, pp. 392-406.

Thaler, Richard H. and Cass R. Sunstein. 2003. “Libertarian Paternalism.” American Economic Review, Vol. 93, No. 2, pp. 175-179.

Thaler, Richard H. and Cass R. Sunstein. 2009. Nudge: Improving Decisions about Health, Wealth, and Happiness. New York: Penguin Press.

Waite, Linda J. and Evelyn L. Lehrer. 2003. “The Benefits from Marriage and Religion in the United States: A Comparative Analysis.” Population and Development Review, Vol. 29, No. 2, pp. 255-275.

Wuthnow, Robert. 1997. The Crisis in the Churches. New York: Oxford University Press. 
Table 1

\section{Happiness and Religious Participation}

\begin{tabular}{|c|c|c|c|}
\hline $\begin{array}{c}\text { Religious Services } \\
\text { Attendance }\end{array}$ & Very Happy & Pretty Happy & Not Happy \\
\hline Never & $26.1 \%$ & $56.5 \%$ & $17.4 \%$ \\
\hline Less Than 1/Year & $26.5 \%$ & $59.5 \%$ & $14.0 \%$ \\
\hline Once/Year & $28.3 \%$ & $59.6 \%$ & $12.2 \%$ \\
\hline 2-3 Times/Year & $29.1 \%$ & $58.5 \%$ & $12.4 \%$ \\
\hline Once/Month & $30.7 \%$ & $58.0 \%$ & $11.3 \%$ \\
\hline 2-3 Times/Month & $31.8 \%$ & $56.3 \%$ & $9.0 \%$ \\
\hline Nearly Weekly & $35.9 \%$ & $55.1 \%$ & $8.7 \%$ \\
\hline Weekly & $39.4 \%$ & $51.9 \%$ & $8.9 \%$ \\
\hline More Than & $46.7 \%$ & $44.4 \%$ & $11.8 \%$ \\
\hline Once/Week & & & $55.4 \%$ \\
\hline All & $32.8 \%$ & & \\
\hline
\end{tabular}

Source: National Opinion Research Center, “General Social Survey: 1972-2004.” 


\begin{tabular}{|c|c|c|c|c|}
\hline \multicolumn{5}{|c|}{ Table 2. Summary statistics } \\
\hline Variable & Mean & $\begin{array}{l}\text { Standard } \\
\text { Deviation }\end{array}$ & Min & Max \\
\hline Happy & 0.89 & 0.31 & 0 & 1 \\
\hline Church attendance & 4.38 & 2.57 & 0 & 8 \\
\hline Repeal & 0.81 & 0.39 & 0 & 1 \\
\hline Number of babies & 0.26 & 0.60 & 0 & 5 \\
\hline Number of preteens & 0.31 & 0.69 & 0 & 6 \\
\hline Number of teens & 0.25 & 0.59 & 0 & 5 \\
\hline Income $(000 \$)$ & 26.27 & 24.53 & 0 & 162.61 \\
\hline Gender (male=1) & 0.42 & 0.49 & 0 & 1 \\
\hline College Graduate & 0.17 & 0.38 & 0 & 1 \\
\hline Some college & 0.21 & 0.41 & 0 & 1 \\
\hline High school dropout & 0.27 & 0.44 & 0 & 1 \\
\hline Age (years) & 46.14 & 17.85 & 18 & 89 \\
\hline African-American & 0.10 & 0.30 & 0 & 1 \\
\hline Hispanic & 0.03 & 0.17 & 0 & 1 \\
\hline Catholic & 0.24 & 0.42 & 0 & 1 \\
\hline Fundamentalist & 0.38 & 0.48 & 0 & 1 \\
\hline $\begin{array}{l}\text { Dummy for living in one of the twelve } \\
\text { largest metropolitan areas }\end{array}$ & 0.09 & 0.29 & 0 & 1 \\
\hline $\begin{array}{l}\text { Dummy for living in one of the thirteenth to } \\
\text { one hundredth metropolitan areas }\end{array}$ & 0.32 & 0.46 & 0 & 1 \\
\hline West & 0.05 & 0.22 & 0 & 1 \\
\hline East & 0.14 & 0.34 & 0 & 1 \\
\hline North & 0.33 & 0.47 & 0 & 1 \\
\hline Married & 0.60 & 0.49 & 0 & 1 \\
\hline State disposable income per capita (000\$) & 15.30 & 6.52 & 4.03 & 29.09 \\
\hline State rate of insured unemployment & 2.50 & 1.39 & 0.7 & 8.4 \\
\hline State percent black & 10.97 & 6.33 & 0.39 & 30.37 \\
\hline State Percent foreign born & 4.78 & 3.77 & 0.66 & 15.94 \\
\hline
\end{tabular}




\begin{tabular}{|c|c|c|c|}
\hline & $\begin{array}{l}\text { Univariate } \\
\text { regressions on }\end{array}$ & \multicolumn{2}{|c|}{$\begin{array}{l}\text { Univariate regressions on the } \\
\text { repeal variable }\end{array}$} \\
\hline & Full sample & Full sample & $\begin{array}{l}+/-2 \\
\text { Discontinuity } \\
\text { sample }\end{array}$ \\
\hline Church attendance & - & $\begin{array}{c}-0.212 \\
(0.084)\end{array}$ & $\begin{array}{c}-0.420 \\
(0.110)\end{array}$ \\
\hline Income $(000 \$)$ & $\begin{array}{c}0.432 \\
(0.108) \\
\end{array}$ & $\begin{array}{c}-2.242 \\
(1.674) \\
\end{array}$ & $\begin{array}{c}0.254 \\
(1.540) \\
\end{array}$ \\
\hline Gender (male=1) & $\begin{array}{c}-0.024 \\
(0.001)\end{array}$ & $\begin{array}{c}0.014 \\
(0.015)\end{array}$ & $\begin{array}{c}-0.004 \\
(0.020)\end{array}$ \\
\hline College Graduate & $\begin{array}{c}0.015 \\
(0.002) \\
\end{array}$ & $\begin{array}{c}0.024 \\
(0.020) \\
\end{array}$ & $\begin{array}{c}0.006 \\
(0.015) \\
\end{array}$ \\
\hline Some college & $\begin{array}{c}0.003 \\
(0.001) \\
\end{array}$ & $\begin{array}{c}-0.026 \\
(0.016) \\
\end{array}$ & $\begin{array}{c}-0.016 \\
(0.019) \\
\end{array}$ \\
\hline High school dropout & $\begin{array}{c}-0.016 \\
(0.002) \\
\end{array}$ & $\begin{array}{c}0.013 \\
(0.018) \\
\end{array}$ & $\begin{array}{c}0.004 \\
(0.022) \\
\end{array}$ \\
\hline Age (years) & $\begin{array}{c}0.862 \\
(0.130)\end{array}$ & $\begin{array}{c}0.247 \\
(1.240)\end{array}$ & $\begin{array}{c}0.498 \\
(1.501)\end{array}$ \\
\hline African-American & $\begin{array}{c}0.008 \\
(0.002) \\
\end{array}$ & $\begin{array}{c}-0.003 \\
(0.021) \\
\end{array}$ & $\begin{array}{c}0.021 \\
(0.019)\end{array}$ \\
\hline Hispanic & $\begin{array}{c}0.001 \\
(0.000)\end{array}$ & $\begin{array}{c}-0.012 \\
(0.010)\end{array}$ & $\begin{array}{c}-0.002 \\
(0.017)\end{array}$ \\
\hline Babies & $\begin{array}{c}0.001 \\
(0.002) \\
\end{array}$ & $\begin{array}{c}-0.060 \\
(0.031) \\
\end{array}$ & $\begin{array}{c}-0.057 \\
(0.034) \\
\end{array}$ \\
\hline Pre-teens & $\begin{array}{c}0.010 \\
(0.003) \\
\end{array}$ & $\begin{array}{c}-0.077 \\
(0.040) \\
\end{array}$ & $\begin{array}{c}-0.060 \\
(0.045) \\
\end{array}$ \\
\hline Teens & $\begin{array}{c}0.004 \\
(0.003) \\
\end{array}$ & $\begin{array}{l}-0.030 \\
(0.022) \\
\end{array}$ & $\begin{array}{c}-0.022 \\
(0.049) \\
\end{array}$ \\
\hline Catholic & $\begin{array}{c}0.012 \\
(0.005) \\
\end{array}$ & $\begin{array}{c}-0.043 \\
(0.027) \\
\end{array}$ & $\begin{array}{l}-0.049 \\
(0.029) \\
\end{array}$ \\
\hline Fundamentalist & $\begin{array}{c}0.012 \\
(0.003)\end{array}$ & $\begin{array}{c}0.027 \\
(0.028)\end{array}$ & $\begin{array}{c}0.074 \\
(0.051)\end{array}$ \\
\hline $\begin{array}{l}\text { Dummy for living in one of the } \\
\text { twelve largest metropolitan areas }\end{array}$ & $\begin{array}{l}-0.000 \\
(0.001)\end{array}$ & $\begin{array}{c}0.090 \\
(0.049)\end{array}$ & $\begin{array}{l}-0.007 \\
(0.016)\end{array}$ \\
\hline $\begin{array}{l}\text { Dummy for living in one of the } \\
\text { thirteenth to one hundredth }\end{array}$ & $\begin{array}{l}-0.005 \\
(0.003) \\
\end{array}$ & $\begin{array}{l}-0.169 \\
(0.098) \\
\end{array}$ & $\begin{array}{c}0.071 \\
(0.050) \\
\end{array}$ \\
\hline West & $\begin{array}{l}-0.000 \\
(0.000) \\
\end{array}$ & $\begin{array}{c}0.000 \\
(0.000) \\
\end{array}$ & - \\
\hline East & $\begin{array}{l}-0.000 \\
(0.000) \\
\end{array}$ & $\begin{array}{l}-0.000 \\
(0.002) \\
\end{array}$ & $\begin{array}{c}-0.143 \\
(0.121) \\
\end{array}$ \\
\hline North & $\begin{array}{l}-0.000 \\
(0.000) \\
\end{array}$ & $\begin{array}{c}0.011 \\
(0.007) \\
\end{array}$ & $\begin{array}{c}0.122 \\
(0.183) \\
\end{array}$ \\
\hline Married & $\begin{array}{c}0.016 \\
(0.003)\end{array}$ & $\begin{array}{l}-0.060 \\
(0.031)\end{array}$ & $\begin{array}{l}-0.009 \\
(0.030)\end{array}$ \\
\hline $\begin{array}{l}\text { State disposable income per capita } \\
(000 \$)\end{array}$ & $\begin{array}{l}-0.001 \\
(0.003)\end{array}$ & $\begin{array}{l}-0.549 \\
(0.370)\end{array}$ & $\begin{array}{c}0.510 \\
(1.379)\end{array}$ \\
\hline State rate of insured unemployment & $\begin{array}{c}0.001 \\
(0.002) \\
\end{array}$ & $\begin{array}{c}0.172 \\
(0.440) \\
\end{array}$ & $\begin{array}{l}-0.051 \\
(0.558) \\
\end{array}$ \\
\hline State percent black & $\begin{array}{l}-0.000 \\
(0.001)\end{array}$ & $\begin{array}{l}-0.171 \\
(0.279)\end{array}$ & $\begin{array}{c}1.501 \\
(1.037)\end{array}$ \\
\hline State Percent foreign born & $\begin{array}{c}0.003 \\
(0.002)\end{array}$ & $\begin{array}{c}0.264 \\
(1.017)\end{array}$ & $\begin{array}{c}0.060 \\
(0.271)\end{array}$ \\
\hline
\end{tabular}


Table 4. OLS estimates of the effect of blue law repeal on church attendance.

\begin{tabular}{|l|c|c|c|c|c|}
\hline & \multicolumn{5}{|c|}{ Whole sample } \\
\hline & $(1)$ & $(2)$ & $(3)$ & $(4)$ & $(5)$ \\
\hline & Basic & Time trend & $\begin{array}{c}\text { Placebo } \\
\text { year }\end{array}$ & $\begin{array}{c}\text { Placebo } \\
\text { region }\end{array}$ & $\begin{array}{c}\text { Placebo } \\
\text { population }\end{array}$ \\
\hline $\begin{array}{l}\text { Repeal dummy } \\
\text { (state clusters) }\end{array}$ & $\begin{array}{c}\mathbf{- 0 . 2 0 9} \\
\mathbf{( 0 . 0 8 3 )}\end{array}$ & $\begin{array}{c}\mathbf{- 0 . 2 8 4} \\
\mathbf{( 0 . 1 2 3 )}\end{array}$ & $\begin{array}{c}-0.265 \\
(0.139)\end{array}$ & & \\
\hline $\begin{array}{l}\text { Placebo dummy } \\
\text { (state clusters) }\end{array}$ & & & $\begin{array}{c}-0.117 \\
(0.156)\end{array}$ & $\begin{array}{c}\mathbf{0 . 1 8 7} \\
\mathbf{( 0 . 0 7 0 )}\end{array}$ & $\begin{array}{c}-0.033 \\
(0.110)\end{array}$ \\
\hline Individual Controls & Yes & Yes & Yes & Yes & Yes \\
\hline State dummies & Yes & Yes & Yes & Yes & Yes \\
\hline Year dummies & Yes & Yes & Yes & Yes & Yes \\
\hline Time Trends & No & Yes & No & No & No \\
\hline Observations & 10,980 & 10,980 & 10,980 & 10,980 & 10,980 \\
\hline R squared & 0.13 & 0.13 & 0.13 & 0.13 & 0.13 \\
\hline
\end{tabular}

Notes: Clustered t-statistics in parentheses. Individual controls include income, age, age squared, race, ethnicity, gender, educational attainment, marital status, religion (Catholic, Fundamentalist), region dummies (west, east and north), a dummy for living in one of the twelve largest metropolitan areas, a dummy for living in one of the thirteenth to one hundredth metropolitan areas and income missing. All regressions include the following state-year variables: state percent African-Americans, state percent foreign born, state disposable income per capita. For each state, we omitted the observations in the year the blue laws were repealed. 


\begin{tabular}{l} 
Table 5. OLS estimates of the effect of blue law repeal on church attendance \\
by gender \\
\hline
\end{tabular}

Notes: Clustered t-statistics in parentheses. Individual controls include income, age, age squared, race, ethnicity, gender, educational attainment, marital status, religion (Catholic, Fundamentalist), region dummies (west, east and north), a dummy for living in one of the twelve largest metropolitan areas, a dummy for living in one of the thirteenth to one hundredth metropolitan areas and income missing. All regressions include the following state-year variables: state percent African-Americans, state percent foreign born, state disposable income per capita. For each state, we omitted the observations in the year the blue laws were repealed. 


\begin{tabular}{|c|c|c|c|c|}
\hline & \multicolumn{2}{|c|}{ Females } & \multicolumn{2}{|c|}{ Males } \\
\hline & White & Black & White & Black \\
\hline $\begin{array}{l}\text { Repeal dummy } \\
\text { (state clusters) }\end{array}$ & $\begin{array}{r}-0.265 \\
(0.081) \\
\end{array}$ & $\begin{array}{c}-0.171 \\
(0.359) \\
\end{array}$ & $\begin{array}{l}-0.155 \\
(0.131) \\
\end{array}$ & $\begin{array}{l}-0.502 \\
(0.376) \\
\end{array}$ \\
\hline Individual Controls & Yes & Yes & Yes & Yes \\
\hline State dummies & Yes & Yes & Yes & Yes \\
\hline Year dummies & Yes & Yes & Yes & Yes \\
\hline Observations & 5,648 & 721 & 4,207 & 404 \\
\hline R squared & 0.12 & 0.17 & 0.15 & 0.14 \\
\hline
\end{tabular}

Notes: Clustered t-statistics in parentheses. Individual controls include income, age, age squared, race, ethnicity, gender, educational attainment, marital status, religion (Catholic, Fundamentalist), region dummies (west, east and north), a dummy for living in one of the twelve largest metropolitan areas, a dummy for living in one of the thirteenth to one hundredth metropolitan areas and income missing. All regressions include the following state-year variables: state percent African-Americans, state percent foreign born, state disposable income per capita. For each state, we omitted the observations in the year the blue laws were repealed. 
Table 7. Naïve estimates of church attendance on happiness

\begin{tabular}{|l|c|c|c|c|c|c|}
\hline & \multicolumn{3}{|c|}{ Logit (marginal effects) } & \multicolumn{3}{c|}{ Linear probability model } \\
\hline & $\begin{array}{c}\text { Full } \\
\text { sample }\end{array}$ & Females & Males & $\begin{array}{c}\text { Full } \\
\text { sample }\end{array}$ & Females & Males \\
\hline $\begin{array}{l}\text { Church attendance } \\
\text { (state clusters) }\end{array}$ & $\begin{array}{c}\mathbf{0 . 0 0 8} \\
\mathbf{( 0 . 0 0 1 )}\end{array}$ & $\begin{array}{c}\mathbf{0 . 0 0 6} \\
\mathbf{( 0 . 0 0 1 )}\end{array}$ & $\begin{array}{c}\mathbf{0 . 0 0 9} \\
\mathbf{( 0 . 0 0 2})\end{array}$ & $\begin{array}{c}\mathbf{0 . 0 0 9} \\
\mathbf{( 0 . 0 0 1 )}\end{array}$ & $\begin{array}{c}\mathbf{0 . 0 0 8} \\
\mathbf{( 0 . 0 0 1 )}\end{array}$ & $\begin{array}{c}\mathbf{0 . 0 1 2} \\
(\mathbf{0 . 0 0 3})\end{array}$ \\
\hline R squared & 0.10 & 0.10 & 0.11 & 0.07 & 0.07 & 0.07 \\
\hline Individual controls & Yes & Yes & Yes & Yes & Yes & Yes \\
\hline State dummies & Yes & Yes & Yes & Yes & Yes & Yes \\
\hline Year dummies & Yes & Yes & Yes & Yes & Yes & Yes \\
\hline Observations & 10,980 & 6,369 & 4,611 & 10,980 & 6,369 & 4,611 \\
\hline
\end{tabular}

Notes: Clustered t-statistics in parentheses. Individual controls include income, age, age squared, race, ethnicity, gender, educational attainment, marital status, religion (Catholic, Fundamentalist Protestant), region dummies (west, east and north), a dummy for living in one of the twelve largest metropolitan areas, a dummy for living in one of the thirteenth to one hundredth metropolitan areas and income missing. All regressions include the following state-year variables: state percent African-Americans, state percent foreign born, state disposable income per capita. For each state, we omitted the observations in the year the blue laws were repealed. The reported R-square for the logit regressions is based on the log likelihood ratio and equals $\mathrm{R}^{2}=1$ - ll (full model) / ll( restricted model). 
Table 8. Logit estimates of the effect of Blue Laws' repeal on happiness

\begin{tabular}{|c|c|c|c|c|c|c|}
\hline & (1) & (2) & (3) & (4) & (5) & (6) \\
\hline & Basic & Basic & Time trend & $\begin{array}{c}\text { Placebo } \\
\text { year }\end{array}$ & $\begin{array}{c}\text { Placebo } \\
\text { region }\end{array}$ & $\begin{array}{c}\text { Placebo } \\
\text { population }\end{array}$ \\
\hline $\begin{array}{l}\text { Repeal } \\
\text { dummy } \\
\text { (state clusters) }\end{array}$ & $\begin{array}{c}-0.181 \\
(0.094)\end{array}$ & $\begin{array}{c}-0.079 \\
(0.093)\end{array}$ & $\begin{array}{c}-0.337 \\
(0.129)\end{array}$ & $\begin{array}{c}-0.219 \\
(0.064)\end{array}$ & & \\
\hline $\begin{array}{l}\text { Placebo } \\
\text { dummy } \\
\text { (state clusters) }\end{array}$ & & & & $\begin{array}{c}-0.076 \\
(0.109)\end{array}$ & $\begin{array}{c}0.077 \\
(0.108)\end{array}$ & $\begin{array}{c}0.143 \\
(0.077)\end{array}$ \\
\hline $\begin{array}{l}\text { Individual } \\
\text { Controls }\end{array}$ & Yes & Yes & Yes & Yes & Yes & Yes \\
\hline State dummies & Yes & Yes & Yes & Yes & Yes & Yes \\
\hline Year dummies & Yes & Yes & Yes & Yes & Yes & Yes \\
\hline Time Trends & No & No & Yes & No & No & No \\
\hline Observations & 10,980 & 10,980 & 10,980 & 10,980 & 10,980 & 10,980 \\
\hline R squared & 0.09 & 0.05 & 0.09 & 0.09 & 0.09 & 0.09 \\
\hline
\end{tabular}

Notes: Clustered t-statistics in parentheses. Individual controls include income, age, age squared, race, ethnicity, gender, educational attainment, marital status, religion (Catholic, Fundamentalist), region dummies (west, east and north), a dummy for living in one of the twelve largest metropolitan areas, a dummy for living in one of the thirteenth to one hundredth metropolitan areas and income missing. All regressions include the following state-year variables: state percent African-Americans, state percent foreign born, state disposable income per capita. For each state, we omitted the observations in the year the blue laws were repealed. The reported R-square is based on the log likelihood ratio and equals $\mathrm{R}^{2}=$ 1 - ll (full model) / ll( restricted model). 
Table 9. Logit estimates of the effect of Blue Laws' repeal on church happiness by gender

\begin{tabular}{|l|c|c|c|c|c|c|}
\hline & \multicolumn{3}{|c|}{ Females } & \multicolumn{3}{c|}{ Males } \\
\hline & Basic & $\begin{array}{c}\text { Time } \\
\text { trend }\end{array}$ & $\begin{array}{c}\text { Placebo } \\
\text { year }\end{array}$ & Basic & $\begin{array}{c}\text { Time } \\
\text { trend }\end{array}$ & $\begin{array}{c}\text { Placebo } \\
\text { year }\end{array}$ \\
\hline $\begin{array}{l}\text { Repeal dummy } \\
\text { (state clusters) }\end{array}$ & $\begin{array}{c}\mathbf{- 0 . 4 6 6} \\
\mathbf{( 0 . 1 3 2 )}\end{array}$ & $\begin{array}{c}\mathbf{- 0 . 5 5 8} \\
\mathbf{( 0 . 2 2 1 )}\end{array}$ & $\begin{array}{c}\mathbf{- 0 . 6 0 4} \\
\mathbf{( 0 . 1 3 1 )}\end{array}$ & $\begin{array}{c}0.161 \\
(0.165)\end{array}$ & $\begin{array}{c}-0.068 \\
(0.283)\end{array}$ & $\begin{array}{c}0.248 \\
(0.172)\end{array}$ \\
\hline $\begin{array}{l}\text { Placebo dummy } \\
\text { (state clusters) }\end{array}$ & & & $\begin{array}{c}-0.277 \\
(0.203)\end{array}$ & & & 0.166 \\
\hline Individual Controls & Yes & Yes & Yes & Yes & Yes & Yes \\
\hline State dummies & Yes & Yes & Yes & Yes & Yes & Yes \\
\hline Year dummies & Yes & Yes & Yes & Yes & Yes & Yes \\
\hline Time Trends & No & Yes & No & No & Yes & No \\
\hline Observations & 6,369 & 6,369 & 6,369 & 4,611 & 4,611 & 4,611 \\
\hline R squared & 0.10 & 0.10 & 0.10 & 0.09 & 0.10 & 0.09 \\
\hline
\end{tabular}

Notes: Clustered t-statistics in parentheses. Individual controls include income, age, age squared, race, ethnicity, gender, educational attainment, marital status, religion (Catholic, Fundamentalist), region dummies (west, east and north), a dummy for living in one of the twelve largest metropolitan areas, a dummy for living in one of the thirteenth to one hundredth metropolitan areas and income missing. All regressions include the following state-year variables: state percent African-Americans, state percent foreign born, state disposable income per capita. For each state, we omitted the observations in the year the blue laws were repealed. The reported R-square is based on the log likelihood ratio and equals $\mathrm{R}^{2}=$ 1 - ll (full model) / ll( restricted model). 1 - ll (full model) / ll( restricted model). 


\begin{tabular}{|c|c|c|c|c|}
\hline & \multicolumn{2}{|c|}{ Females } & \multicolumn{2}{|c|}{ Males } \\
\hline & White & Black & White & Black \\
\hline $\begin{array}{l}\text { Repeal dummy } \\
\text { (state clusters) }\end{array}$ & \begin{tabular}{|l|}
-0.408 \\
$(0.096)$ \\
\end{tabular} & $\begin{array}{l}-0.379 \\
(0.556) \\
\end{array}$ & $\begin{array}{c}0.214 \\
(0.174) \\
\end{array}$ & $\begin{array}{c}0.577 \\
(0.933) \\
\end{array}$ \\
\hline Individual Controls & Yes & Yes & Yes & Yes \\
\hline State dummies & Yes & Yes & Yes & Yes \\
\hline Year dummies & Yes & Yes & Yes & Yes \\
\hline Observations & 5,648 & 704 & 4,207 & 390 \\
\hline R squared & 0.09 & 0.13 & 0.09 & 0.24 \\
\hline
\end{tabular}

Notes: Clustered t-statistics in parentheses. Individual controls include income, age, age squared, race, ethnicity, gender, educational attainment, marital status, religion (Catholic, Fundamentalist), region dummies (west, east and north), a dummy for living in one of the twelve largest metropolitan areas, a dummy for living in one of the thirteenth to one hundredth metropolitan areas and income missing. All regressions include the following state-year variables: state percent African-Americans, state percent foreign born, state disposable income per capita. For each state, we omitted the observations in the year the blue laws were repealed. The reported R-square is based on the log likelihood ratio and equals $\mathrm{R}^{2}=$ 1 - ll (full model) / ll( restricted model). 


\begin{tabular}{|c|c|c|c|c|c|c|}
\hline & \multicolumn{3}{|c|}{ Church attendance } & \multicolumn{3}{|c|}{ Happiness } \\
\hline & (1) & $(2)$ & (3) & (4) & (5) & (6) \\
\hline & Basic & $\begin{array}{l}\text { Time } \\
\text { trend }\end{array}$ & $\begin{array}{l}\text { Placebo } \\
\text { dummy }\end{array}$ & Basic & $\begin{array}{l}\text { Time } \\
\text { trend }\end{array}$ & $\begin{array}{l}\text { Placebo } \\
\text { dummy }\end{array}$ \\
\hline $\begin{array}{l}\text { Without individual and } \\
\text { state controls }\end{array}$ & $\begin{array}{c}-0.212 \\
(0.084)\end{array}$ & $\begin{array}{l}-0.279 \\
(0.114)\end{array}$ & $\begin{array}{l}-0.234 \\
(0.120)\end{array}$ & $\begin{array}{l}-0.234 \\
(0.121)\end{array}$ & $\begin{array}{l}-0.326 \\
(0.103)\end{array}$ & $\begin{array}{l}-0.273 \\
(0.154)\end{array}$ \\
\hline $\begin{array}{l}\text { With individual and state } \\
\text { controls }\end{array}$ & $\begin{array}{r}-0.209 \\
(0.083)\end{array}$ & $\begin{array}{l}-0.284 \\
(0.123) \\
\end{array}$ & $\begin{array}{r}-0.265 \\
(0.139) \\
\end{array}$ & $\begin{array}{l}-0.181 \\
(0.094)\end{array}$ & $\begin{array}{r}-0.337 \\
(0.129)\end{array}$ & $\begin{array}{l}-0.219 \\
(0.064) \\
\end{array}$ \\
\hline Number of observations & 10,980 & 10,980 & 10,980 & 10,980 & 10,980 & 10,980 \\
\hline
\end{tabular}

Notes: Clustered t-statistics in parentheses. Individual controls include income, age, age squared, race, ethnicity, gender, educational attainment, marital status, religion (Catholic, Fundamentalist), region dummies (west, east and north), a dummy for living in one of the twelve largest metropolitan areas, a dummy for living in one of the thirteenth to one hundredth metropolitan areas and income missing. All regressions include the following state-year variables: state percent African-Americans, state percent foreign born, state disposable income per capita. For each state, we omitted the observations in the year the blue laws were repealed. The reported R-square is based on the log likelihood ratio and equals $\mathrm{R}^{2}=$ 1 - ll (full model) / ll( restricted model). 


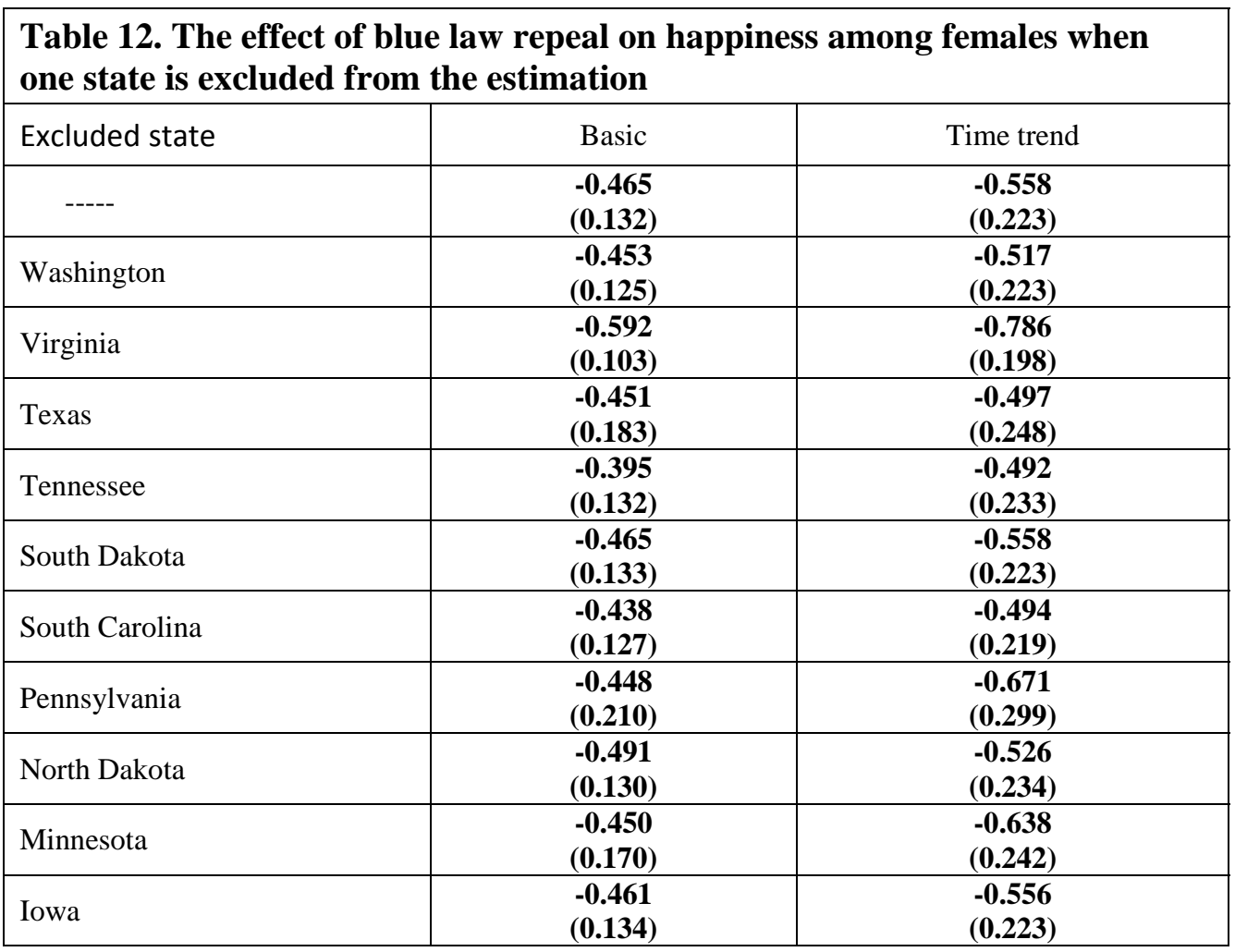

Notes: Clustered t-statistics in parentheses. Individual controls include income, age, age squared, race, ethnicity, gender, educational attainment, marital status, religion (Catholic, Fundamentalist), region dummies (west, east and north), a dummy for living in one of the twelve largest metropolitan areas, a dummy for living in one of the thirteenth to one hundredth metropolitan areas and income missing. All regressions include the following state-year variables: state percent African-Americans, state percent foreign born, state disposable income per capita. For each state, we omitted the observations in the year the blue laws were repealed. The reported R-square is based on the log likelihood ratio and equals $\mathrm{R}^{2}=$ 1 - ll (full model) / ll( restricted model). 


\begin{tabular}{|c|c|c|c|c|}
\hline \multicolumn{6}{|c|}{$\begin{array}{l}\text { Table 13. The effect of blue law repeal on church attendance, happiness and } \\
\text { work-related variables by gender within a discontinuity sample }\end{array}$} \\
\hline & Church attendance & Happiness & Job satisfaction & $\begin{array}{c}\text { Weekly hours } \\
\text { worked }\end{array}$ \\
\hline $\begin{array}{c}\text { Full discontinuity } \\
\text { sample }\end{array}$ & $\mathbf{- 0 . 4 2 0}$ & $\mathbf{- 0 . 0 2 4}$ & -0.015 & 0.309 \\
\hline Females & $\mathbf{0 . 1 1 0 )}$ & $\mathbf{( 0 . 0 1 2}$ & $(0.021)$ & $(0.915)$ \\
\hline \multirow{2}{*}{ Males } & $\mathbf{- 0 . 5 6 6}$ & $\mathbf{- 0 . 0 4 3}$ & -0.024 & -0.055 \\
& $\mathbf{( 0 . 2 0 4 )}$ & $\mathbf{( 0 . 0 2 0}$ & $(0.032)$ & $(1.283)$ \\
\hline-0.234 & 0.001 & -0.003 & 1.033 \\
& $(0.179)$ & $(0.021)$ & $(0.033)$ & $(1.849)$ \\
\hline
\end{tabular}

Notes: Clustered t-statistics in parentheses. For each state, we omitted the observations in the year the blue laws were repealed. The reported R-square for the logit regressions is based on the log likelihood ratio and equals $\mathrm{R}^{2}=1$ - $\mathrm{ll}$ (full model) / ll( restricted model). 


\begin{tabular}{|c|c|c|c|c|}
\hline & Full sample & Non-workers & All females & $\begin{array}{c}\text { Non-working } \\
\text { Females }\end{array}$ \\
\hline $\begin{array}{l}\text { Repeal dummy } \\
\text { (state clusters) }\end{array}$ & $\begin{array}{l}-0.181 \\
(0.094)\end{array}$ & $\begin{array}{l}-0.352 \\
(0.159)\end{array}$ & $\begin{array}{l}-0.466 \\
(0.132)\end{array}$ & $\begin{array}{c}-0.474 \\
(0.169)\end{array}$ \\
\hline Individual Controls & Yes & Yes & Yes & Yes \\
\hline State dummies & Yes & Yes & Yes & Yes \\
\hline Year dummies & Yes & Yes & Yes & Yes \\
\hline Observations & 10,980 & 4,414 & 6,369 & 3,156 \\
\hline $\mathrm{R}$ squared & 0.09 & 0.10 & 0.10 & 0.11 \\
\hline
\end{tabular}

Notes: Clustered t-statistics in parentheses. Individual controls include income, age, age squared, race, ethnicity, gender, educational attainment, marital status, religion (Catholic, Fundamentalist), region dummies (west, east and north), a dummy for living in one of the twelve largest metropolitan areas, a dummy for living in one of the thirteenth to one hundredth metropolitan areas and income missing. All regressions include the following state-year variables: state percent African-Americans, state percent foreign born, state disposable income per capita. For each state, we omitted the observations in the year the blue laws were repealed. The reported R-square is based on the log likelihood ratio and equals $\mathrm{R}^{2}=$ 1 - ll (full model) / ll( restricted model). 


\begin{tabular}{|c|c|c|c|c|}
\hline & \multicolumn{2}{|c|}{ Job satisfaction } & \multicolumn{2}{|c|}{ Hours worked } \\
\hline & Full sample & Females & Full sample & Females \\
\hline $\begin{array}{l}\text { Repeal } \\
\text { (state clusters) }\end{array}$ & $\begin{array}{c}0.028 \\
(0.100)\end{array}$ & $\begin{array}{c}0.031 \\
(0.095)\end{array}$ & $\begin{array}{l}-0.343 \\
(0.585)\end{array}$ & $\begin{array}{l}-0.172 \\
(0.787)\end{array}$ \\
\hline Individual Controls & Yes & Yes & Yes & Yes \\
\hline State dummies & Yes & Yes & Yes & Yes \\
\hline Year dummies & Yes & Yes & Yes & Yes \\
\hline Time Trends & No & No & No & No \\
\hline Observations & 8,657 & 5,113 & 6,393 & 3,116 \\
\hline R squared & 0.04 & 0.05 & 0.13 & 0.10 \\
\hline
\end{tabular}

Notes: Clustered t-statistics in parentheses. Individual controls include income, age, age squared, race, ethnicity, gender, educational attainment, marital status, religion (Catholic, Fundamentalist), region dummies (west, east and north), a dummy for living in one of the twelve largest metropolitan areas, a dummy for living in one of the thirteenth to one hundredth metropolitan areas and income missing. All regressions include the following state-year variables: state percent African-Americans, state percent foreign born, state disposable income per capita. For each state, we omitted the observations in the year the blue laws were repealed. The reported R-square is based on the log likelihood ratio and equals $\mathrm{R}^{2}=$ 1 - ll (full model) / ll( restricted model). 


\begin{tabular}{|c|c|c|c|}
\hline & Full sample & Females & Males \\
\hline $\begin{array}{l}\text { Repeal } \\
\text { (state clusters) }\end{array}$ & $\begin{array}{c}-0.213 \\
(0.088) \\
\end{array}$ & $\begin{array}{c}-0.481 \\
(0.084) \\
\end{array}$ & $\begin{array}{c}0.096 \\
(0.197) \\
\end{array}$ \\
\hline $\begin{array}{l}\text { Repeal * teens } \\
\text { (state clusters) }\end{array}$ & $\begin{array}{c}0.082 \\
(0.139)\end{array}$ & $\begin{array}{c}0.038 \\
(0.168)\end{array}$ & $\begin{array}{c}0.169 \\
(0.157)\end{array}$ \\
\hline Individual Controls & Yes & Yes & Yes \\
\hline State dummies & Yes & Yes & Yes \\
\hline Year dummies & Yes & Yes & Yes \\
\hline Time Trends & No & No & No \\
\hline Observations & 10,980 & 6,369 & 4,611 \\
\hline R squared & 0.09 & 0.10 & 0.09 \\
\hline
\end{tabular}

Notes: Clustered t-statistics in parentheses. Individual controls include income, age, age squared, race, ethnicity, gender, educational attainment, marital status, religion (Catholic, Fundamentalist), region dummies (west, east and north), a dummy for living in one of the twelve largest metropolitan areas, a dummy for living in one of the thirteenth to one hundredth metropolitan areas and income missing. All regressions include the following state-year variables: state percent African-Americans, state percent foreign born, state disposable income per capita. For each state, we omitted the observations in the year the blue laws were repealed. The reported R-square for the logit regressions is based on the log likelihood ratio and equals $\mathrm{R}^{2}=1$ - ll (full model) / ll( restricted model). 
Table 17. IV estimates of the effect of church attendance on happiness

\begin{tabular}{|l|c|c|c|c|c|}
\hline & \multicolumn{5}{|c|}{ Full sample } \\
\hline & $(1)$ & $(2)$ & $(3)$ & $(4)$ & $(5)$ \\
\hline & Basic & $\begin{array}{c}\text { Time } \\
\text { trend }\end{array}$ & $\begin{array}{c}\text { Placebo } \\
\text { Year }\end{array}$ & Basic & $\begin{array}{c}\text { Basic } \\
\text { (Females) }\end{array}$ \\
\hline $\begin{array}{l}\text { Church attendance } \\
\text { (state clusters) }\end{array}$ & $\begin{array}{c}0.073 \\
(0.048)\end{array}$ & $\begin{array}{c}0.059 \\
(0.033)\end{array}$ & $\begin{array}{c}0.066 \\
(0.046)\end{array}$ & $\begin{array}{c}0.103 \\
(0.061)\end{array}$ & $\begin{array}{c}0.156 \\
(0.062)\end{array}$ \\
\hline $\begin{array}{l}\text { AR F-statistic of significance of } \\
\text { church attendance (state clustered, } \\
\text { p-value in parentheses) }\end{array}$ & $\begin{array}{c}2.88 \\
(0.11)\end{array}$ & $\begin{array}{c}6.11 \\
(0.03)\end{array}$ & $\begin{array}{c}5.76 \\
(0.03)\end{array}$ & $\begin{array}{c}3.41 \\
(0.08)\end{array}$ & $\begin{array}{c}14.75 \\
(0.00)\end{array}$ \\
\hline $\begin{array}{l}\text { First stage F-statistic on excluded } \\
\text { instruments }\end{array}$ & 6.66 & 5.66 & 3.88 & 6.81 & 11.97 \\
\hline Individual Controls & Yes & Yes & Yes & No & Yes \\
\hline State dummies & Yes & Yes & Yes & Yes & Yes \\
\hline Year dummies & Yes & Yes & Yes & Yes & Yes \\
\hline Time Trends & No & Yes & No & No & No \\
\hline Observations & 10,980 & 10,980 & 10,980 & 10,980 & 6,369 \\
\hline
\end{tabular}

Notes: Clustered t-statistics in parentheses. Individual controls include income, age, age squared, race, ethnicity, gender, educational attainment, marital status, religion (Catholic, Fundamentalist), region dummies (west, east and north), a dummy for living in one of the twelve largest metropolitan areas, a dummy for living in one of the thirteenth to one hundredth metropolitan areas and income missing. All regressions include the following state-year variables: state percent African-Americans, state percent foreign born, state disposable income per capita. For each state, we omitted the observations in the year the blue laws were repealed. 


\begin{tabular}{|c|c|c|}
\hline & Full sample & Females \\
\hline $\begin{array}{l}\text { Years after the repeal } \\
\text { (state clusters) }\end{array}$ & $\begin{array}{c}0.021 \\
(0.178)\end{array}$ & $\begin{array}{l}-0.054 \\
(0.182)\end{array}$ \\
\hline Individual Controls & Yes & Yes \\
\hline State dummies & Yes & Yes \\
\hline Year dummies & Yes & Yes \\
\hline Time Trends & No & No \\
\hline Observations & 8,925 & 5,203 \\
\hline $\mathrm{R}$ squared & 0.13 & 0.11 \\
\hline
\end{tabular}

Notes: Clustered t-statistics in parentheses. Individual controls include income, age, age squared, race, ethnicity, gender, educational attainment, marital status, religion (Catholic, Fundamentalist), region dummies (west, east and north), a dummy for living in one of the twelve largest metropolitan areas, a dummy for living in one of the thirteenth to one hundredth metropolitan areas and income missing. All regressions include the following state-year variables: state percent African-Americans, state percent foreign born, state disposable income per capita. For each state, we omitted the observations in the year the blue laws were repealed. The reported R-square for the logit regressions is based on the log likelihood ratio and equals $\mathrm{R}^{2}=1$ - ll (full model) / ll( restricted model). 
Table 19. Explaining the puzzling decline in Happiness over time

\begin{tabular}{|c|c|c|c|c|}
\hline & \multicolumn{2}{|c|}{ Females } & \multicolumn{2}{|c|}{ Males } \\
\hline & OLS & IV & OLS & OLS \\
\hline Year & $\begin{array}{l}-0.009 \\
(0.004)\end{array}$ & $\begin{array}{l}-0.006 \\
(0.009)\end{array}$ & $\begin{array}{l}-0.005 \\
(0.006)\end{array}$ & $\begin{array}{l}-0.008 \\
(0.006)\end{array}$ \\
\hline $\begin{array}{l}\text { Repeal dummy } \\
\text { (state clusters) }\end{array}$ & & & & $\begin{array}{c}0.025 \\
(0.015)\end{array}$ \\
\hline $\begin{array}{l}\text { Church attendance } \\
\text { (state clusters) }\end{array}$ & & $\begin{array}{c}0.124 \\
(0.058)\end{array}$ & & \\
\hline Individual Controls & + & + & + & + \\
\hline State dummies & + & - & + & + \\
\hline Year dummies & - & - & - & - \\
\hline $\begin{array}{l}\text { F-statistic on excluded } \\
\text { instrument }\end{array}$ & & 8.35 & & \\
\hline Observations & 6369 & 6369 & 4611 & 4611 \\
\hline R squared & 0.06 & & 0.06 & 0.06 \\
\hline
\end{tabular}

Notes: Clustered t-statistics in parentheses. Individual controls include income, age, age squared, race, ethnicity, gender, educational attainment, marital status, religion (Catholic, Fundamentalist), region dummies (west, east and north), a dummy for living in one of the twelve largest metropolitan areas, a dummy for living in one of the thirteenth to one hundredth metropolitan areas and income missing. All regressions include the following state-year variables: state percent African-Americans, state percent foreign born, state disposable income per capita. For each state, we omitted the observations in the year the blue laws were repealed. 